\title{
ANALISIS RISIKO PRODUKSI SUSU KAMBING PERANAKAN ETAWA PADA KELOMPOK TANI MANDIRI DI DESA WISATA NGANGGRING
}

\author{
Risk Production Analysis of Peranakan Etawa Goats Milk at Kelompok Tani \\ Mandiri in Desa Wisata Nganggring
}

\author{
Rismayanti Maimunah, Budiarto dan Juarini \\ Program Studi Agribisnis Jurusan Agribisnis Fakultas Pertanian Universitas \\ Pembangunan Nasional Veteran Yogyakarta \\ Jl. SWK 104 (Lingkar Utama) Condongcatur Yogyakarta Indonesia 55283 \\ *email korespondensi : rismaym@,gmail.com
}

Diterima tanggal : 21 September 2020 ; Disetujui tanggal : 2 Oktober 2020

\begin{abstract}
This study aimed to analyze the risk production of peranakan etawa goat's milk at Kelompok Tani Mandiri. This study used descriptive method, the method of execution used was survey method, the methode of location determination was purposive. The method of sampling used was sensus for 30 members of Kelompok Tani Mandiri. Kinds of data used in this study were primary datas and secondary datas. The techniques collection of data used were interviews and observations. The techniques analysis of data used were RFMEA analysis to describe the production risk event and coefficient variation analysis to analyze the production risk. The result of this study showed there are 6 risk events for goat milk production experienced by independent farmer groups, namely bad quality of goats, insufficient of feed, goats affected by disease, goats fail to get pregnant, goats have miscarriages, and goats die during childbirth. The risk events that have the highest occurence and severity is the risk of the insufficient of feed and goats affected by disease. The risk level of production risk in Kelompok Tani Mandiri is low.
\end{abstract}

Keyword: Goat's Milk, Production, Risk, Risk Management

\begin{abstract}
ABSTRAK
Penelitian ini bertujuan untuk mendeskripsikan kejadian risiko produksi dan menganalisis risiko produksi susu kambing peranakan etawa pada Kelompok Tani Mandiri di desa wisata Nganggring. Penelitian ini menggunakan metode deskriptif, metode pelaksanaan penelitian menggunakan metode survei, metode penentuan lokasi dilakukan secara sengaja (purposif), metode pengambilan responden menggunakan metode sensus untuk 30 orang anggota Kelompok Tani Mandiri. Macam data yang digunakan adalah data primer dan data sekunder. Teknik pengambilan data dengan wawancara dan observasi. Teknik analisis data menggunakan analisis RFMEA untuk mendeskripsikan kejadian risiko produksi dan analisis koefisien variasi untuk menganalisis risiko produksi . Hasil penelitian ini menunjukkan bahwa terdapat 6 kejadian risiko produksi susu kambing yang
\end{abstract}


dialami oleh Kelompok Tani Mandiri yaitu kualitas kambing tidak baik, kebutuhan pakan tidak terpenuhi, kambing terserang penyakit, kambing gagal bunting, kambing mengalami keguguran, dan induk kambing mati saat melahirkan. Tidak terdapat kejadian risiko dengan status ekstrem dan tinggi, kejadian risiko paling besar dialami kelompok Tani Mandiri berstatus moderat yaitu kebutuhan pakan tidak terpenuhi dan kambing terserang penyakit. Tingkat risiko produksi yang dialami oleh kelompok Tani Mandiri rendah.

Kata kunci: Susu Kambing, Produksi, Risiko, Pengelolaan Risiko

\section{PENDAHULUAN}

Kambing merupakan salah satu ternak yang memiliki potensi tinggi untuk dikembangkan. Pemanfaatan ternak kambing di dalam negeri umumnya dalam bentuk daging dan susu. Walaupun tidak sebanyak daging, pemanfaatan susu kambing sudah banyak ditemui saat ini. Bahkan, susu dari jenis kambing tertentu memiliki kandungan protein dan khasiat yang lebih tinggi dibanding susu sapi. Kambing Peranakan Etawa (PE) merupakan salah satu jenis kambing yang mempunyai potensi untuk menghasilkan susu yang saat ini sudah mulai tersebar luas di Indonesia. Kambing PE adalah hasil persilangan antara kambing jamnapari dari India dengan kambing kacang dari Indonesia. Kambing PE dikenal dengan kambing dwiguna yaitu penghasil daging dan susu (Destomo, et.al., 2020).

Salah satu provinsi yang membudidayakan kambing PE adalah Daerah Istimewa Yogyakarta. Pengembangan kambing PE di Daerah Yogyakarta dinilai mampu meningkatkan pendapatan petani dari hasil penjualan daging, susu dan kotoran yang dijadikan pupuk, salah satunya di Kabupaten Sleman. Pemerintah Kabupaten Sleman (2017) menyebutkan bahwa populasi ternak kambing PE di Kabupaten Sleman mencapai 5.994 ekor. Populasi kambing tersebut tersebar di 9 Kecamatan dari 17 Kecamatan di Kabupaten Sleman, 8 kelompok dengan 539 anggota.

Kecamatan Turi yang berada di Kabupaten Sleman terkenal dengan Desa Agro Wisata kambing PE. Banyak orang dari dalam maupun luar kota dari berbagai kalangan yang berkunjung dalam rangka study tour ataupun pelatihan wirausaha bagi yang ingin memulai usaha kambing PE. Salah satu kelompok 
Maimunah et.al. Analisis Risiko Produksi Susu Kambing Peranakan Etawa Pada..

ternak di Kecamatan Turi adalah kelompok Mandiri sebagai kelompok perintis Desa Agro Wisata kambing PE.

Hasil utama yang didapatkan oleh kelompok tani Mandiri dari budidaya kambing PE adalah susu kambing. Susu kambing memiliki nilai jual yang cukup tinggi yaitu mencapai Rp.20.000,00 / liter. Namun, pada kenyataannya, hasil yang diterima peternak kelompok tani Mandiri masih kurang maksimal karena terjadi fluktuasi produksi susu kambing.

Crane, et al (2013) menyatakan bahwa risiko produksi adalah setiap aktivitas atau kegiatan yang berhubungan dengan produksi yang memiliki kemungkinan ketidakpastian hasil. Penyebab terjadinya risiko produksi bermacam-macam, bisa dari faktor genetik, keadaan suhu dan cuaca, penyakit, dan lain-lain. Setiap peternak perlu melakukan pengelolaan risiko produksi untuk meminimalisir kerugian yang harus ditanggung. Berdasarkan latar belakang tersebut penelitian ini bertujuan untuk mendeskripsikan kejadian risiko produksi dan menganalisis risiko produksi susu kambing peranakan etawa pada Kelompok Tani Mandiri di Desa Wisata Nganggring.

\section{METODE PENELITIAN}

Metode dasar yang digunakan dalam penelitian ini adalah metode deskriptif. Metode pelaksanaan penelitian ini adalah metode survei. Metode survei adalah penyelidikan yang diadakan untuk memperoleh fakta-fakta dari gejala-gejala yang ada dan mencari keterangan-keterangan secara faktual, baik tentang institusi sosial, ekonomi, atau politik dari suatu kelompok ataupun suatu daerah (Nazir, 2017).

Penelitian ini dilakukan di Kelompok Tani Mandiri Desa Wisata Nganggring, Girikerto, Turi, Sleman berdasarkan pertimbangan bahwa kelompok Tani Mandiri memiliki populasi kambing paling banyak di Girikerto. Metode pengambilan responden menggunakan metode sensus dengan jumlah responden sebanyak 30 orang. Macam data yang digunakan adalah data primer dan data sekunder. Metode pengumpulan data yang digunakan yaitu observasi dan wawancara. 
Jurnal Dinamika Sosisal Ekonomi, 21 (2) : 178-189

\section{Analisis Deskripsi Kejadian Risiko Produksi Susu Kambing Peranakan Etawa}

Analisis deskripsi kejadian risiko produksi susu kambing peranakan etawa dilakukan dengan pendekatan Risk Failure Mode and Effect Analysis (RFMEA). RFMEA bertujuan untuk menentukan tingkat risiko dari setiap jenis kegagalan sehingga dapat diambil keputusan. Penentuan tingkat risiko menggunakan RFMEA yaitu dengan melakukan penilaian tingkat occurance atau frekuensi dan severity atau dampak risiko (Suryaningrat, et.al., 2019). Tabel 1 menunjukkan skala occurence dan severity.

Tabel 1 Skala Occurence dan Severity

\begin{tabular}{cc}
\hline Skala & Makna \\
\hline $9-10$ & Frekuensi dan dampak risiko sangat tinggi \\
$7-8$ & Frekuensi dan dampak risiko tinggi \\
$5-6$ & Frekuensi dan dampak risiko moderat \\
$3-4$ & Frekuensi dan dampak risiko rendah \\
$1-2$ & Frekuensi dan dampak risiko sangat rendah \\
\hline
\end{tabular}

Sumber: Hanif, et.al., 2015

Setelah diketahui besar skala occurence dan severity, langkah selanjutnya adalah pembuatan matriks risiko. Matriks tersebut dapat dilihat pada gambar 1.

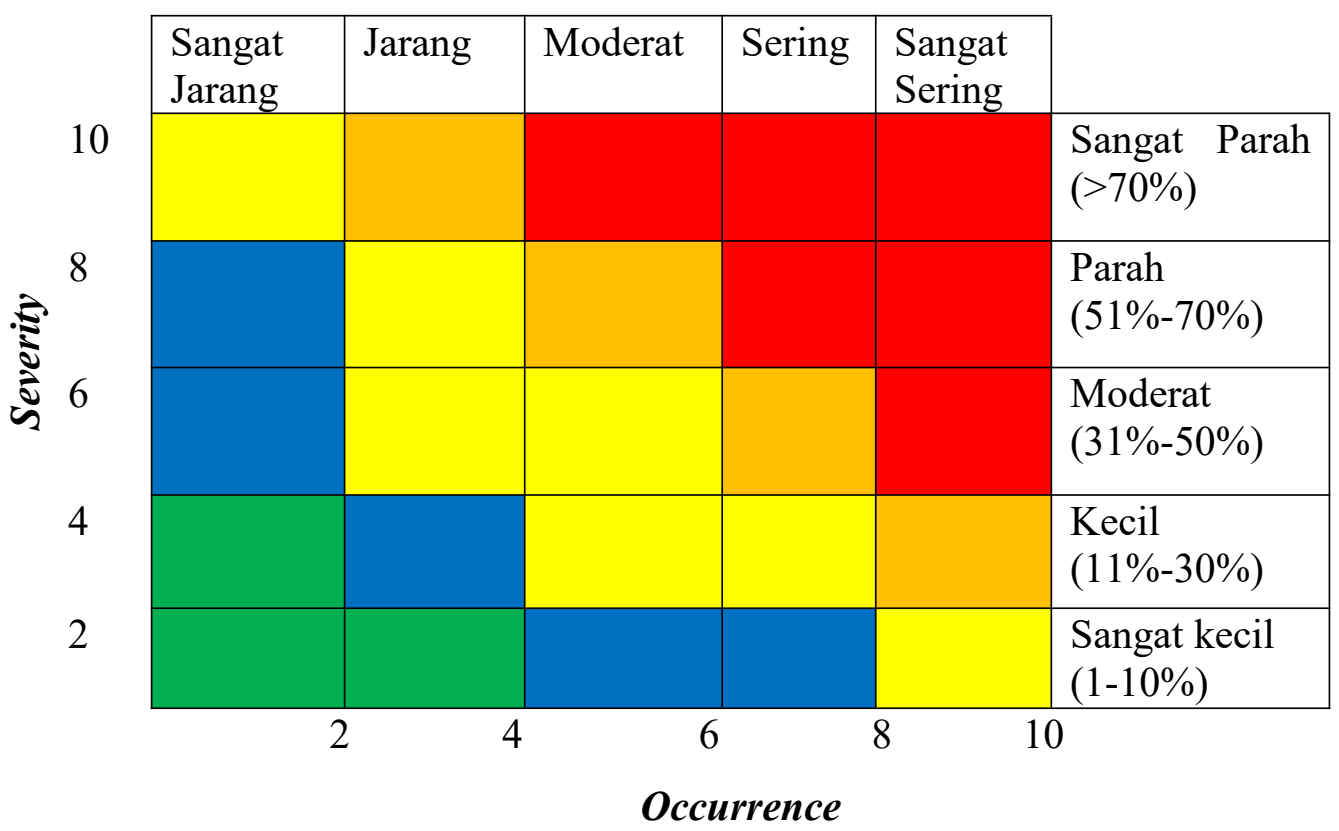

Gambar 1 Matriks Risiko Produksi Susu 
Maimunah et.al. Analisis Risiko Produksi Susu Kambing Peranakan Etawa Pada..

Sumber: Hasiah, et.al., 2016

Gambar 1 menunjukkan matriks risiko yang akan digunakan untuk memetakan posisi setiap kejadian risiko yang didasarkan pada nilai occurence dan severity. Posisi dari setiap kejadian risiko menentukan status risiko yang dibagi menjadi 5 status risiko. Risiko dengan status sangat rendah ditandai dengan warna hijau, status risiko rendah warna biru, status risiko moderat warna kuning, status risiko tinggi warna jingga dan status risiko ekstrem ditandai dengan matriks berwarna merah.

\section{Analisis Risiko Produksi Susu Kambing Peranakan Etawa}

Analisis risiko produksi dilakukan dengan menggunakan simpangan baku (standard deviation) dan koefisien variasi. Pengukuran simpangan baku digunakan untuk mengetahui besarnya penyimpangan pada pengamatan sebenarnya di sekitar nilai rata-rata produksi. Ukuran untuk nilai rata-rata (mean), pengukuran dirumuskan sebagai berikut :

$$
\bar{x}=\frac{\sum_{i=1}^{n} x i}{n}
$$

Keterangan :

$\bar{x}=$ rata-rata produksi susu

$x i=$ produksi susu tiap bulan

$n=$ periode pemerahan

Untuk menghitung simpangan baku (standard deviation) digunakan rumus berikut :

$$
\sigma=\sqrt{\frac{\sum_{i=1}^{n}(x i-\bar{x})^{2}}{n-1}}
$$

\section{Keterangan :}

$\sigma=$ simpangan baku (standard deviation)

$\bar{x}=$ rata-rata produksi susu

$x i=$ produksi susu tiap bulan

$n=$ periode pemerahan 
Pengukuran terhadap risiko dapat dianalisis dengan menentukan besarnya koefisien variasi $(\mathrm{KV})$. Koefisien variasi merupakan perbandingan antara risiko yang harus ditanggung peternak dengan keuntungan yang akan diperoleh sebagai hasil dari sejumlah modal yang diinvestasikan dalam proses produksi (Asaad, et.al., 2019). Koefisien variasi merupakan ukuran risiko relatif yang diperoleh dengan membagi standar deviasi dengan nilai rata-rata yang diharapkan (Kurniati et.al., 2014).

$$
K V=\frac{\sigma}{E} \times 100 \%
$$

\section{Keterangan :}

$\mathrm{KV}=$ Koefisien variasi risiko produksi susu

$\sigma \quad=$ standar deviasi risiko produksi susu

$E \quad=$ rata-rata hasil produksi susu

Nilai KV berbanding lurus dengan risiko yang dihadapi peternak, artinya semakin besar nilai KV yang didapat maka semakin besar pula risiko yang harus ditanggung petani. Begitu pula sebaliknya, semakin rendah nilai KV yang diperoleh maka risiko yang harus ditanggung petani akan semakin kecil (Susanti et al, 2017).

\section{HASIL PEMBAHASAN}

\section{Analisis Deskripsi Kejadian Risiko Produksi Susu Kambing Peranakan Etawa}

Analisis Deskripsi Kejadian Risiko Produksi Susu Kambing Peranakan Etawa dilakukan dengan pendekatan Risk Failure Mode and Effect Analysis (RFMEA). Penilaian yang dilakukan meliputi level occurence atau frekuensi terjadinya risiko dan level severity atau dampak risiko yang ditimbulkan terhadap hasil yang diharapkan apabila risiko tersebut terjadi. Penilaian terhadap risiko dilakukan dengan cara menyebarkan kuesioner kepada 30 orang anggota Kelompok Tani Mandiri sebagai responden.

Hasil penilaian responden terhadap frekuensi dan dampak risiko produksi susu kambing tersebut kemudian diambil modusnya atau angka yang paling sering muncul dari 30 responden untuk kemudian dilakukan analisis risiko produksi 
Maimunah et.al. Analisis Risiko Produksi Susu Kambing Peranakan Etawa Pada..

dengan metode RFMEA. Analisis risiko produksi susu kambing PE pada Kelompok Tani Mandiri dengan metode RFMEA dapat dilihat pada tabel 3.

Tabel 3 Analisis Risiko Produksi Susu Kambing PE pada Kelompok Tani Mandiri dengan Metode RFMEA

\begin{tabular}{clcc}
\hline $\begin{array}{c}\text { Kode } \\
\text { Risiko }\end{array}$ & \multicolumn{1}{c}{ Kejadian Risiko } & $\begin{array}{c}\text { Frekuensi } \\
\text { (Occurence) }\end{array}$ & Dampak (Severity) \\
\hline E1 & $\begin{array}{l}\text { Kualitas Kambing tidak } \\
\text { baik }\end{array}$ & 3 & 2 \\
E2 & $\begin{array}{l}\text { Kebutuhan pakan tidak } \\
\text { tercukupi }\end{array}$ & 5 & 3 \\
E3 & $\begin{array}{l}\text { Kambing terserang } \\
\text { penyakit }\end{array}$ & 5 & 3 \\
E4 & $\begin{array}{l}\text { Kambing gagal bunting } \\
\text { Kambing mengalami } \\
\text { keguguran pada usia } \\
\text { kandungan kurang dari } \\
\text { 4 bulan }\end{array}$ & 3 & 3 \\
E5 & 2 & 2 \\
Enduk kambing mati & 1 & 1 \\
\hline
\end{tabular}

Sumber : Analisis Data Primer, 2020

Dari tabel 3 dapat diketahui skala frekuensi dan dampak masing-masing kejadian risiko. Selanjutnya dibuat matriks risiko berdasarkan skala tersebut untuk mengetahui status masing-masing kejadian risiko. Matriks risiko dapat dilihat pada gambar 2 .

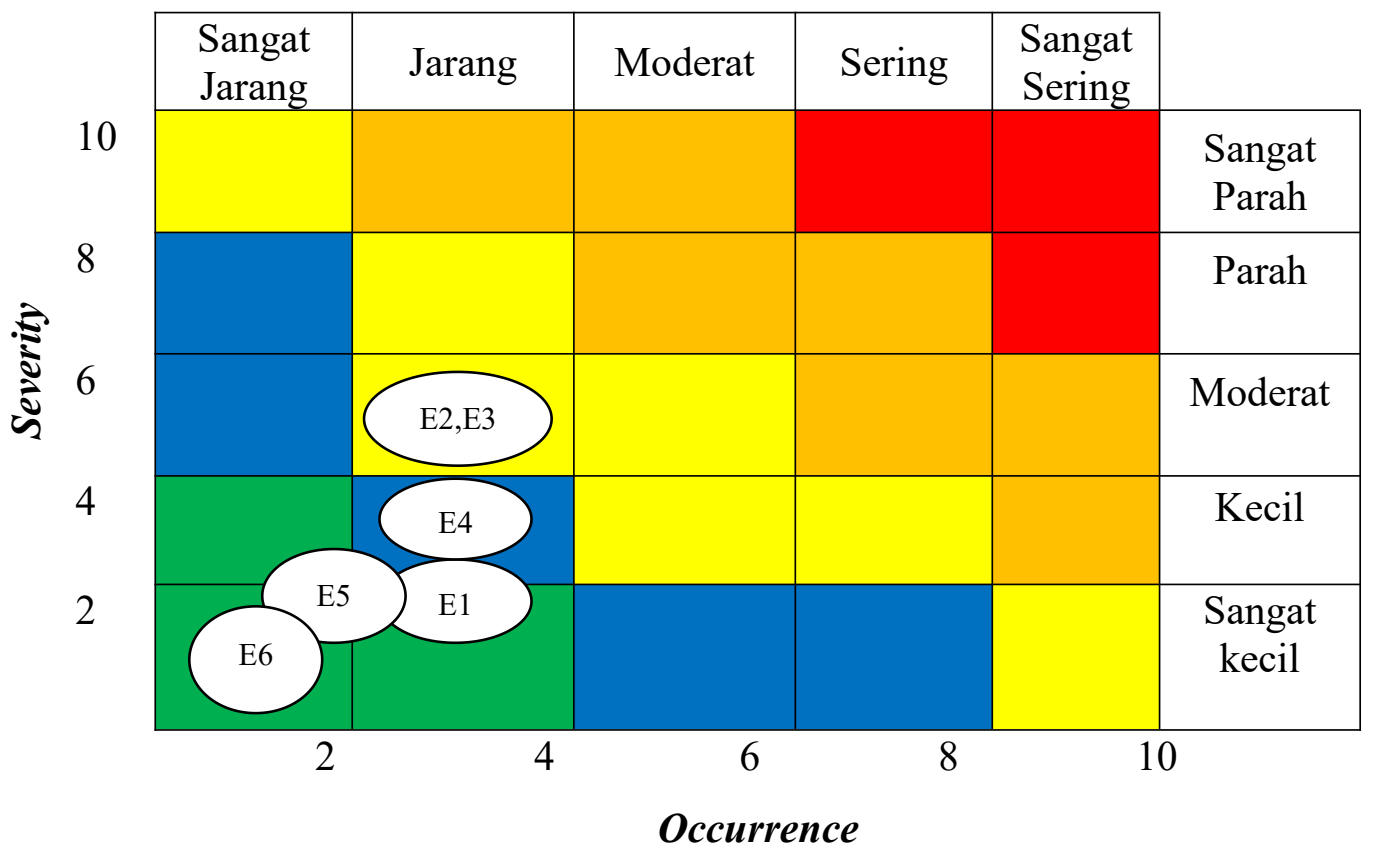


Jurnal Dinamika Sosisal Ekonomi, 21 (2) : 178-189

Gambar 2 Matriks Risiko Produksi Susu Kambing PE pada Kelompok Tani Mandiri

Sumber: Analisis Data Sekunder, 2020

\section{Kebutuhan Pakan Tidak Terpenuhi (Moderat)}

Pakan untuk kambing perah terdiri dari 2 jenis yaitu pakan hijauan dan komboran (campuran konsentrat polard, kulit kacang kedelai, ampas tahu, dan air). Kebutuhan pakan hijauan adalah $1 \mathrm{~kg} /$ hari untuk satu ekor kambing dan komboran sebanyak 2,5 kg/hari untuk satu ekor kambing. Anggota kelompok tani Mandiri memperoleh pakan hijauan dengan cara mencari sendiri, namun pada saat musim kemarau, pakan hijauan sulit ditemukan sehingga pakan harian untuk kambing kadang tidak dapat terpenuhi. Anggota kelompok tani Mandiri menyiasati hal ini dengan membeli pakan berupa kulit kacang hijau yang harganya murah. Kendala dari membeli kulit kacang hijau ini adalah terkadang pakan datang terlambat sehingga kebutuhan pakan untuk kambing beberapa kali tidak terpenuhi.

\section{Kambing Terserang Penyakit (Moderat)}

Penyakit yang sering menyerang kambing di kelompok tani Mandiri adalah kembung, cacingan, diare, penyakit kutu, kudis, dan mastitis. Faktorfaktor yang meyebabkan kambing terserang penyakit antara lain, lingkungan kandang yang lembap, kondisi cuaca iklim yang tidak menentu, kesalahan dalam memberi pakan, dan waktu pemerahan susu yang berubah-ubah.

\section{Kambing Gagal Bunting (Rendah)}

Untuk menghasilkan susu, kambing harus melalui tahap reproduksi terlebih dahulu, salah satunya adalah perkawinan. Beberapa perkawinan pada kambing tidak menyebabkan kambing bunting. Penyebab kambing gagal bunting pada kelompok tani Mandiri adalah karena perkawinan kambing dilakukan kurang tepat waktu. Menurut penilaian responden, kambing gagal bunting sebanyak 2 kali dari 10 kali perkawinan dan menyebabkan produksi susu berkurang sampai 10\% - 20\%. 
Maimunah et.al. Analisis Risiko Produksi Susu Kambing Peranakan Etawa Pada..

\section{Kualitas Kambing Tidak Baik (Sangat Rendah - Rendah)}

Anggota kelompok tani Mandiri sebagian besar memperoleh kambing perah dengan cara membeli, hanya beberapa saja yang memperanakkan sendiri. Saat membeli kadang petani kurang detail melihat keadaan kambing. Dari 10 kali pengadaan kambing, biasanya peternak mendapatkan bibit kualitas tidak baik sebanyak 2 kali dan menyebabkan penurunan produksi susu sebasar 11\% $20 \%$.

\section{Kambing Mengalami Keguguran pada Usia Kandungan Kurang dari 4}

\section{Bulan (Sangat Rendah - Rendah)}

Banyak faktor yang menyebabkan kambing mengalami keguguran. Pada kelompok tani Mandiri, keguguran pada kambing disebabkan oleh kondisi kandang yang kadang basah dan licin sehingga kambing mudah tergelincir dan kondisi kambing yang kekurangan nutrisi. Menurut penilaian responden, dari 10 kali kehamilan, biasanya hanya 1 kali kambing mengalami keguguran dan menyebabkan penurunan produksi susu sampai 10\%.

\section{Induk Kambing Mati Saat Melahirkan (Sangat Rendah)}

Faktor-faktor yang menyebabkan kematian pada induk kambing saat melahirkan di antaranya, kekurangan nutrisi, terinfeksi virus atau bakteri, dan serangan penyakit. Risiko induk kambing mati saat melahirkan termasuk ke dalam risiko sangat jarang terjadi, bahkan mayoritas responden mengatakan bahwa dalam 10 kali kelahiran, tidak pernah ada induk kambing yang mati.

\section{Analisis Risiko Produksi Susu Kambing Peranakan Etawa}

Analisis Risiko Produksi Susu Kambing Peranakan Etawa dilakukan dengan pendekatan koefisien variasi. Koefisien variasi didapatkan dari hasil bagi antara standar deviasi hasil produksi susu dengan rata-rata hasil produksi susu. Analisis risiko produksi susu kambing peranakan etawa pada kelompok tani Mandiri di desa wisata Nganggring dengan metode koefisien variasi dapat dilihat pada tabel 4. 
Jurnal Dinamika Sosisal Ekonomi, 21 (2) : 178-189

Tabel 4 Analisis Risiko Produksi Susu Kambing PE pada Kelompok Tani Mandiri Tahun 2018

\begin{tabular}{|c|c|c|c|}
\hline Bulan & $\begin{array}{c}\text { Jumlah } \\
\text { Produksi Susu } \\
\text { (Liter) }\end{array}$ & $\begin{array}{l}\text { Jumlah } \\
\text { Kambing } \\
\text { Laktasi } \\
\text { (Ekor) }\end{array}$ & $\begin{array}{c}\text { Rata-Rata Produksi } \\
\text { Susu } \\
\text { (Liter/Ekor) }\end{array}$ \\
\hline Januari & 5163,45 & 175 & 29,51 \\
\hline Februari & 4816,30 & 168 & 28,67 \\
\hline Maret & 3007,05 & 150 & 20,05 \\
\hline April & 2541,25 & 141 & 18,02 \\
\hline Mei & 2609,10 & 136 & 19,18 \\
\hline Juni & 3997,30 & 140 & 28,55 \\
\hline Juli & 3002,75 & 158 & 19,00 \\
\hline Agustus & 3791,35 & 183 & 20,72 \\
\hline September & 5961,20 & 200 & 29,81 \\
\hline Oktober & 5655,20 & 191 & 29,61 \\
\hline November & 3449,80 & 165 & 20,91 \\
\hline Desember & 2835,00 & 153 & 18,53 \\
\hline \multicolumn{3}{|c|}{ Jumlah Produksi Susu dalam satu tahun (Liter) } & $46.829,75$ \\
\hline \multicolumn{3}{|c|}{ Rata-rata produksi susu (Liter/ekor/bulan) } & $\mathbf{2 3 , 5 5}$ \\
\hline \multicolumn{3}{|c|}{ Standar Deviasi } & 5,09 \\
\hline \multicolumn{3}{|c|}{ Koefisien Variasi } & $\mathbf{0 , 2 2}$ \\
\hline
\end{tabular}

Sumber : Analisis Data Sekunder, 2020

Berdasarkan tabel 4 jumlah produksi susu kambing bulan Januari-Desember 2018 sebesar 46.829,75 liter dengan rata-rata produksi tiap bulan sebesar 23,55 liter / ekor. Nilai standar deviasi sebesar 5,09. Nilai koefisien variasi produksi susu kambing peranakan etawa pada kelompok tani Mandiri adalah sebesar 0,22 atau $22 \%$. Maka risiko produksi susu kambing peranakan etawa pada Kelompok Tani Mandiri termasuk dalam risiko rendah.

\section{KESIMPULAN DAN SARAN}

\section{Kesimpulan}

Terdapat 6 kejadian risiko produksi susu kambing yang dialami oleh Kelompok Tani Mandiri yaitu kualitas kambing tidak baik, kebutuhan pakan tidak terpenuhi, kambing terserang penyakit, kambing gagal bunting, kambing mengalami keguguran, dan induk kambing mati saat melahirkan. Tidak terdapat kejadian risiko dengan status ekstrem dan tinggi, kejadian risiko paling besar dialami kelompok Tani Mandiri berstatus moderat yaitu kebutuhan pakan tidak 
Maimunah et.al. Analisis Risiko Produksi Susu Kambing Peranakan Etawa Pada..

terpenuhi dan kambing terserang penyakit. Tingkat risiko produksi yang dialami oleh kelompok Tani Mandiri rendah dengan nilai koefisien variasi sebesar 22\%.

\section{Saran}

Sebaiknya peternak lebih teliti dalam membeli kambing dan memilih breeder yang handal agar mendapatkan kambing dengan kualitas unggul. Apabila pakan hijauan melimpah saat musim penghujan dapat dibuat pakan silase untuk mengantisipasi kulit kacang hijau yang terlambat datang sehingga kambing tetap mendapat asupan pakan yang cukup. Selain itu, sebaiknya peternak lebih memperhatikan kebersihan kandang kambing agar tidak menjadi tempat berkembang biak bagi bakteri penyebab penyakit kambing. Kelompok Tani Mandiri juga dapat mengajukan permohonan kepada penyedia fasilitas kesehatan hewan bersubsidi seperti Puskeswan atau Dinas Peternakan setempat agar kambing mendapatkan pemerikasaan secara rutin dengan biaya yang rendah sebagai upaya meminimalisir kambing terserang penyakit. Agar tidak terjadi kegagalan kebuntingan pada kambing, sebaiknya peternak mencatat waktu kawin dan melahirkan kambing sehingga peternak dapat memperkirakan waktu perkawinan selanjutnya.

\section{DAFTAR PUSTAKA}

Asaad, A., Asaf, R., Athirah, A., dan Ratnawati, E. (2019). Analisis Resiko Produksi dan Pendapatan pada Usaha Budi Daya Tambak Udang Windu di Kabupaten Kotabaru, Provinsi Kalimantan Selatan. Jurnal Sosial Ekonomi Kelautan dan Perikanan, 14(2) : 125-134

Crane, L., Gantz, G., Isaacs, S., Jose, D., Sharp, R. (2013). Introduction to Risk Management Understanding Agricultural Risks: Production, Marketing, Financial, Legal, Human ( $\left.2^{\text {nd }} e d\right)$. USA: Extension Risk Management Education and Risk Management Agency

Destomo, A., Syawal, M., Batubara A. (2020). Kemampuan Reproduksi Induk dan Pertumbuhan Anak Kambing Peranakan Etawah, Gembrong, dan Kosta. Jurnal Peternakan, 17 (1) : 31-38

Hanif, R., Rukmi, H., Susanty, S. (2015). Perbaikan Kualitas Produk Keraton Luxury di PT. X dengan Menggunakan Metode Failure Mode And Effect Analysis (FMEA) dan Fault Tree Analysis (FTA). Jurnal Institut Teknologi Nasional, 3 (3) : 137-147

Hasiah., Arsyad, M., Sukriah. (2016). Desain Model Matriks Penilaian Risiko (Risk Assessment) dalam Perencanaan Audit Umum (Studi pada Satuan 
Jurnal Dinamika Sosisal Ekonomi, 21 (2) : 178-189

Pengawas Internal (SPI), Bagian Keuangan dan Bagian Pengadaan Barang dan Jasa Politeknik Negeri Ujung Pandang). Jurnal Ilmiah Akuntansi dan Keuangan, 3 (1) : 42-60

Kurniati, D., Hartono, S., Widodo, S., dan Suryantini, A. (2014). Risiko Pendapatan pada Usahatani Jeruk Siam di Kabupaten Sambas. Journal Social Economic of Agriculture, 3(2) : 12-19

Nazir. 2017. Metode Penelitian. Bogor: Ghalia Indonesia

Pemerintah Kabutapen Sleman. 2017. Optimalkan Hasil Ternak, Rumah Pengolahan Pakan Kambing PE Nganggring Diresmikan. www.slemankab.go.id (Diakses pada tanggal 12 Maret 2019 pukul 14.25 WIB)

Suryaningrat, I., Febrianti, W., dan Amilia, W. (2019). Identifikasi Risiko pada Okra Menggunakan Failure Mode And Effect Analysis (FMEA) di PT. Mitratani Dua Tujuh di Kabupaten Jember. Jurnal Agroteknologi, 13(1) : 25-33

Susanti, D., Widjaja, S., dan Abidin, Z. (2017). Analisis Resiko Penangkar Benih Padi pada Program Desa Mandiri Benih di Kabupaten Pringsewu. Journal of Food System and Agribusiness. 1(2) : 38-42 